\title{
Assessment of the feasibility of applying an excess-profits tax from hydrocarbon production for deposits at the final stage of development
}

\author{
Larisa Rudneva ${ }^{1, *}$, Olga Rudenok $^{1}$, and Svetlana Larionova ${ }^{1}$ \\ ${ }^{1}$ Tyumen Industrial University, 625000, 38, Volodarsky st., Tyumen, Russia
}

\begin{abstract}
The author's approaches to the feasibility of applying an excessprofits tax from hydrocarbon production to various types of deposits are reflected. The possibility of applying this tax in the operation of an oil field at the final stage of development is studied. A comparative assessment of the technical and economic performance of the field under consideration under the current and new tax regimes was carried out. Based on the modeling of scenarios for the development of the world oil market, its parameters have been determined, under which the development of the field using the new tax regime will ensure economic and budgetary efficiency.
\end{abstract}

\section{Introduction}

Taxation of hydrocarbon production in the Russian Federation has always been the subject of disputes and discussions among government officials, scientists and practitioners. Since it affects the interests of the state, which budget is largely formed from tax revenues from oil and gas companies, and subsoil users themselves, whose sustainable development opportunities depend on the size of paid taxes on oil and gas production.

In the period 2002-2018 the system of taxation of oil production was based solely on gross indicators and was changed in two directions: 1) increase in the total rate of mineral extraction tax (MET), introduced from 01.01.2002, and export duty; 2) provision of various benefits to tax payers. The excess-profit tax from the production of hydrocarbons (EPT) introduced in the Russian Federation from 01.01.2019 is based on taxation of the economic results of oil companies, which corresponds to the global trend. But it does not imply the extension on the entire industry due to the current inexpediency of completely eliminating taxation of the gross income of oil companies.

The aim of this work is to justify the need and feasibility of expanding the scope of EPT for oil production in connection with a change in the current macroeconomic situation in the subsoil area that are not included in the group of "pilot" projects, but meeting the requirements of article 333.45 of the Tax Code of the Russian Federation.

\footnotetext{
* Corresponding author: $\underline{\ln . r u d n e v a @ \text { mail.ru }}$
} 


\section{Materials and methods}

The theoretical and methodological basis of the study was the work of scientists and practitioners in the field of taxation of oil production in the Russian Federation, as well as regulatory documents reflecting the introduction of a excess-profit tax from hydrocarbon production in the Russian Federation. The information base of the study was made up of statistical materials reflecting the activities of the oil and gas company.

The research was conducted using general scientific methods and techniques, such as scientific abstraction, comparative and logical analysis and synthesis, analogy and modeling, and a structural-level approach.

\section{Results and discussion}

The feature of modern stage of development of the oil industry in the Russian Federation is the prevalence proved reserves in the structure of oil reserves, located in developed fields with a high degree of depletion, and the increase in the proportion of hard-to-recover reserves (HTR) due to primary mining of easy-to-recover reserves. The majority of large oil and gas fields in the Western Siberia are currently being developed at the late (final) stages of development. One of these fields is the Svetloye field, which is operated by LLC "Sabunneftegaz" (the names of the field and the Company are conditional).

The Svetloye field, discovered in 1971, has been in development since 1976 and is currently in the fourth stage of development with an annual oil production rate of less than 0.5 million tons. The water content of production is $94 \%$, which causes a high cost of oil production. In the structure of the cost of sales of LLC "Sabunneftegaz" tax payments make up more than $60 \%$, of which $99 \%$ is taken by the tax on mining [1]. As a rule, fields at the final stage of development show low profitability due to increased costs and high tax burden, which has the most significant impact on the overall cost of sales. This leads to unprofitable development of mature assets and lack of opportunities to invest in new efficient technologies for extracting hard-to-recover reserves. In this situation, taxation issues for license areas at the final stages of development become particularly relevant.

Since January 1, 2019, a new tax regime for oil and gas companies has been applied in Russia - the excess-profit tax from hydrocarbon production. The purpose of this tax is to ensure the budgetary and economic efficiency of oil fields development, including lowprofit ones that require attracting large amounts of investment. In contrast to the current system of taxation based on gross indicators, the new tax regime, which involves the withdrawal of part of the financial result of the activities of mining companies, takes into account the real economy of projects for the development of subsurface areas.

The introduction of the excess-profit tax from the hydrocarbon production has attracted wide interest from the scientific community, practitioners and government representatives. The high level of discussion of this issue is due to the ambiguity of the world experience of introducing similar tax regimes for state budgets, for investors and for mining companies themselves. According to most analysts, the main reasons for adjusting the tax system of the Russian oil and gas sector are the following: high tax burden on mining companies and lack of incentives to maintain their long-term investment activity, as well as unequal conditions for companies with different portfolio assets due to the use of "point" incentives for hydrocarbon production [2-4].

The application of the new tax regime has a number of advantages, which are as follows: 1) providing differentiation in the tax burden of oil companies in accordance with the terms of oil production in specific fields; 2) creation of more favorable economic conditions for development of fields with high production costs, stimulating the production of hard-to-recover reserves and ensuring the necessary return on investment for the investor 
by transferring the fiscal burden to later stages of development; 3) ensuring more rational use of the subsoil and additional flow of tax revenues to the state budget at the expense of increasing the volume of oil extraction [2, 5-7].

During the discussion of the draft of excess-profit tax, many objective questions arose about the problems that arise during using the new tax mechanism. One of them is to strengthen the process of tax administration due to the risk of reducing state revenues due to overstating expenses by mining companies [5-7]. The practice of applying the EPT in 2019 has shown that the solution to this problem is provided by the adoption of internal regulatory documents on accounting for actual costs, the development of methodological approaches to the distribution of operating expenses for the purposes of calculating the EPT, and their coordination with the tax authorities.

Most experts believe that the application of the new tax regime is possible only in a favorable macroeconomic situation for subsurface areas belonging to the so-called "greenfields" and located in both new and traditional regions of oil production. At the same time, according to Gert A.A., Nemova O.G. and Kuzmina K.N. [8], the transition to EPT will not always stimulate the development of even these fields in the long term, especially after the end of the tax grace period in the context of lower oil sales prices. The same opinion is held by Bobylev Yu. N., who notes that under favorable macroeconomic conditions, the state's share of net income when using EPT can be from 54 to $64 \%$, and the internal rate of return on investment - from 8.9 to $19.7 \%$ [6]. Accordingly, the deterioration of the macroeconomic situation will lead to a decrease in the budget and economic efficiency of oil production, including the development of new fields.

According to a number of analysts, there is no expediency of applying EPT for hard-torecover "mature" oil fields. Kashirina M.V. and Zhuravlev M.A., [7] explain this by two reasons: 1) the development of these fields is on the verge of profitability and the application of EPT in relation to them is not effective from a budgetary point of view due to the lack of additional profit; 2) there is no need for tax incentives in these fields to attract investments that have already been invested in the development [7]. In our view, this point of view is controversial. Production of hard-to-recover oil reserves requires the use of new innovative production technologies to increase the oil recovery coefficient. Under the traditional tax regime based on MET, mining companies do not have their own funds to invest in the development and implementation of such technologies, which leads to the termination of oil production at license areas with high cost. Thus, at the end of 2019, a number of producing companies, including PJSC Gazprom Neft and PJSC Lukoil, noted the effectiveness of applying EPT even for certain hard-to-recover "mature" fields [9].

Currently, the EPT is introduced in a limited number of license areas. Provisions of article 333. 45. The new version of the Tax Code of the Russian Federation, effective from 01.04.2020, provides for the application of the new tax regime to 5 groups of license areas [10]. According to the law, the Svetloye field meets the criteria of group 3 of licensed subsoil plots: it is a "mature" site, located completely within the borders of the KhMADYugra. As of 01.01.2017 it has been in development for more than six years and has a degree of depletion of oil reserves of at least $10 \%$ and no more than $80 \%$. The total production of oil and gas condensate for 2016 in accordance with the state balance of mineral reserves does not exceed 15 million tons. This indicates the possibility of applying a new tax regime for the operation of this field.

To justify the feasibility of applying EPT at the Svetloye field, forecast calculations of the main indicators of its development under the existing and new tax regime were made by the income approach using discounted cash flows (the discount rate is $10 \%$ ). The accounting period is 20 years, and the price of Urals oil is \$57.0. US/barrel, the US dollar/ruble exchange rate -65.7 , the total volume of oil production -9.33 million tons, the 
amount of capital investment required in new technologies for the production of hard-torecover reserves - 27.03 billion rubles (18.23 billion rubles, including discounting).

Currently, Sabunneftegaz LLC pays taxes stipulated by the Tax Code of the Russian Federation during the development of the Svetloye field; mandatory payments established by the "Law on subsoil" and the customs legislation of the Russian Federation. A comparative assessment of tax payments under the compared tax regimes for the Svetloye field showed that as a result of applying the EPT, tax deductions, taking into account the specifics of the field's development, will be lower than the existing ones by $17.0 \%$ or by 24.6 billion rubles. (Fig. 1).

This is primarily due to a 50\% MET reduction in the EPT regime. It should be noted that in the total amount of tax deductions in the EPT regime, the share of the MET in the average period will be $68.5 \%$. According to the years of the accounting period, the share of MET varies from $81.9 \%$ during the period of highest production to $58.6 \%$ by the end of the accounting period. Consequently, the application of EPT for the Svetloye field will reduce the cost of oil sold by reducing the tax component, which will affect the net cash flow (NCF) of Sabunneftegaz LLC for this license area (Fig. 2).

Under the current tax regime (CTR), continuation of the development of the Svetloye field becomes unprofitable. Accumulated net discounted cash flow (ANDCF) is negative. Current (operating) costs associated with oil production are not repaid. To make capital investments to maintain the current level of oil production, it is necessary to attract borrowed funds, which will lead to an increase in the cost of production at this license area.

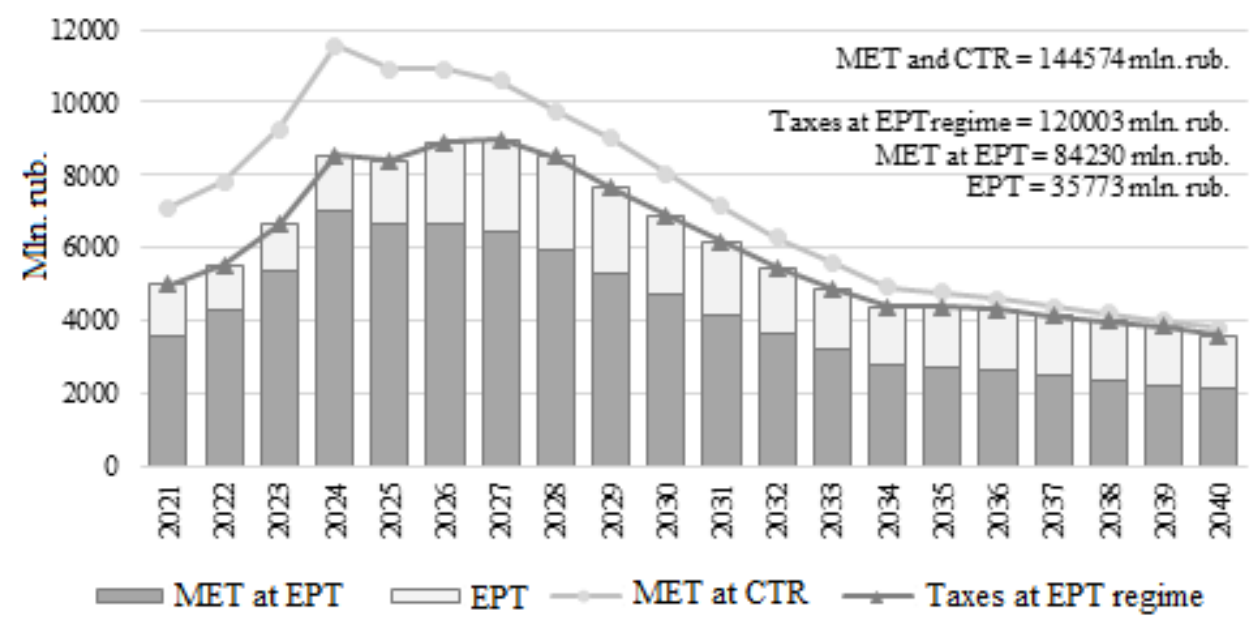

Fig. 1. Tax payments of the Svetloye field under two taxation regimes in 2021-2040 


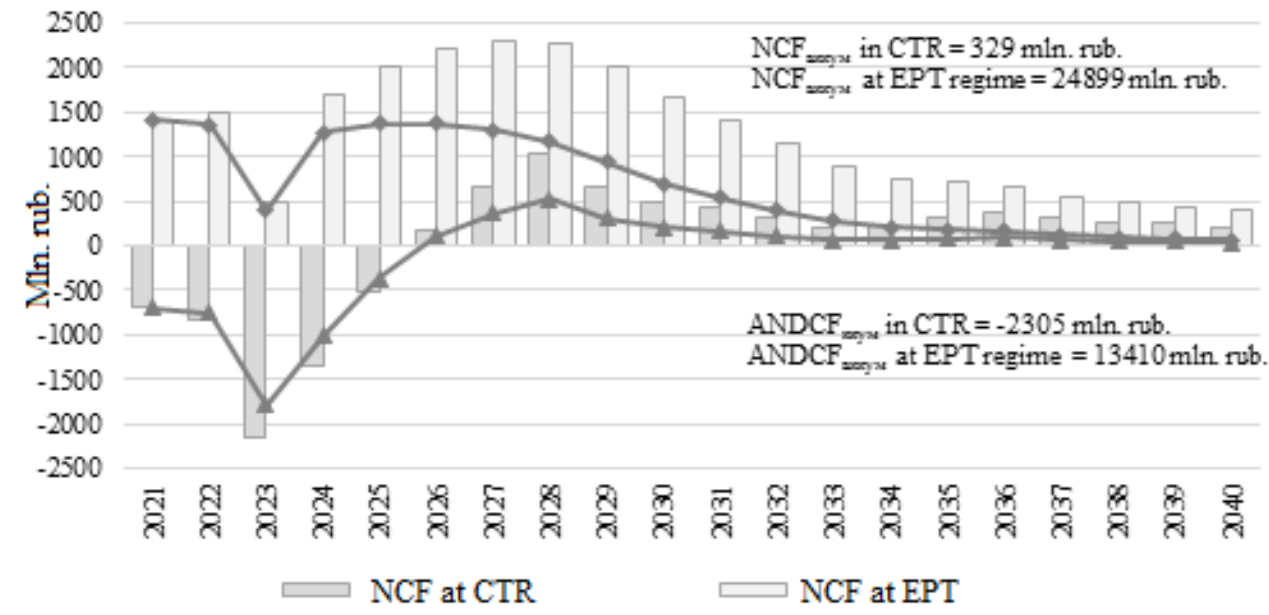

Fig. 2. Net cash and net discounted cash flows for the Svetloye field in 2021-2040

In the EPT regime, the accumulated net discounted cash flow has a positive value and according to forecast data may amount to more than 13 billion rubles for the entire accounting period. There will be own sources of investment to new technologies to maintain the current level of oil production. The application of the EPT regime will cover the need for investment at the expense of own funds in the period from 2021 to 2026 by 57 $\%$ (10.3 billion rubles) and get available cash assets in the following years in the amount of more than 3 billion rubles, which can be used to increase production volumes through the use of various technological solutions, including innovative ones (Fig. 3).

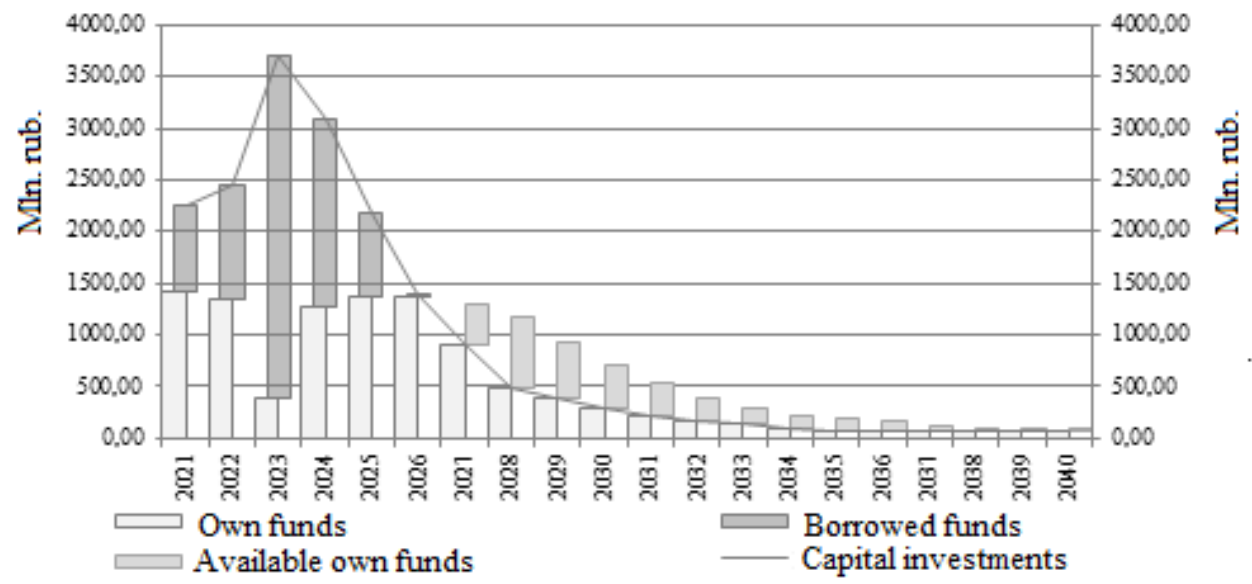

Fig. 3. Structure of capital investments to maintain the current level of oil production by sources of coverage under the EPT regime for the Svetloye field in 2021-2040

The possible increase in oil production at the Svetloye field as a result of the application of EPT may amount to about 1.6 million tons, or $17 \%$ of the planned production level. This change in the volume of oil production will help to increase the financial results of the mining company and increase the budget efficiency of the field development. 
In order to identify the possibility of further development of the Svetloye field, a simulation of net discounted cash flow was performed under the EPT regime for the field under various conditions of the world oil market (Fig. 4).

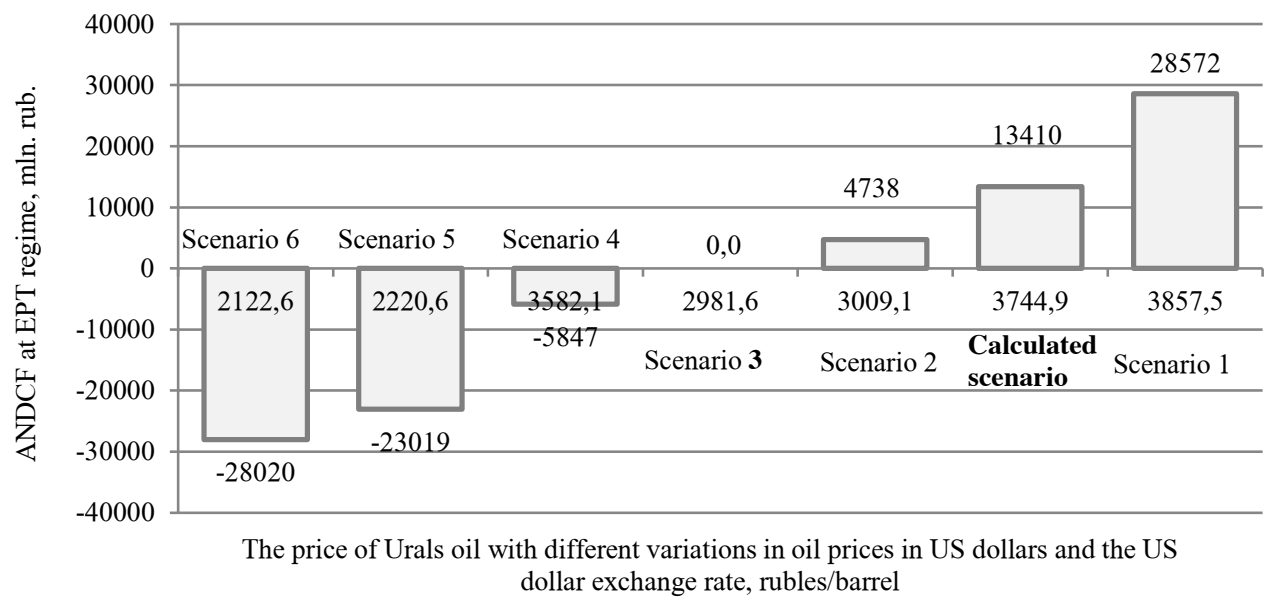

Estimated scenario: Urals price $=57 \$ / \mathrm{bbl}$; US dollar exchange rate $=65.7 \mathrm{RUB} / \$$

Scenario 1: Urals price $=55.133333 \$ / \mathrm{bbl}$; US dollar exchange rate $=69.96667 \mathrm{RUB} / \$$

Scenario 2: Urals Price $=43.297286 \$ / \mathrm{bbl}$; US dollar exchange rate $=69.498482 \mathrm{RUB} / \$$

Scenario 3: Urals price $=40.37059 \$ / \mathrm{bbl}$; US dollar exchange rate $=73.854711 \mathrm{RUB} / \$$

Scenario 4: Urals price $=50.333 \$ / \mathrm{bbl}$; US dollar exchange rate $=71.16667 \mathrm{RUB} / \$$

Scenario 5: Urals price $=30.06 \$ / \mathrm{bbl}$; US dollar exchange rate $=73.8725 \mathrm{RUB} / \$$

Scenario 6: Urals price $=28.95 \$ / \mathrm{bbl}$; US dollar exchange rate $=73.3183 \mathrm{RUB} / \$$

Fig. 4. Net discounted cash flow under the EPT regime for the Svetloye field under various conditions of the world oil market in 2021-2040

The study conducted suggests that the continuation of the development of the Svetloye field in the EPT regime is possible only under more favorable macroeconomic conditions than the current crisis conditions caused by the COVID-19 virus pandemic (Scenarios 5 and $6)$.

Modeling of net discounted cash flow under the EPT regime for the Svetloye field based on the data of the budget forecast of the Russian Federation for the period up to 2036 [11] showed the inefficiency of further development of the field under a conservative scenario of dynamics of Urals oil prices and the US dollar exchange rate (Scenario 4). In the basic scenario, further development of the field is possible with full coverage of the need to invest new technologies to maintain the current level of oil production and obtain available cash (Scenario 1).

The break-even threshold for the development of this field is reached if the price of Urals oil is not lower than 2981.56 rubles/barrel or 40.37059 dollars. US/barrel at the exchange rate of the US dollar to the Russian ruble - 73.854711, which corresponds to Scenario 3. While continuing the development of this field under the current tax regime is inefficient even in favorable macroeconomic conditions. In the event of further deterioration of the global oil market, further exploitation of the Svetloye field will not be effective under the new tax regime.

\section{Conclusions}

The results of the conducted study allow us to conclude that the use of the new tax regime at a field with falling production will be appropriate only in favorable macroeconomic 
conditions and will contribute to increasing the volume of production of hard-to-recover oil, increasing the budget efficiency of the development of this field.

\section{References}

1. L. N. Rudneva, S.S. Larionova, Problems of sustainable development: industrial and regional aspect. 2, 335-340 (2019).

2. A. S. Balandina, Siberian Financial School 3, 46-49 (2017)

3. V. V. Ponkratov, Oil economy, 9, 58-61 (2014).

4. V. V. Ponkratov, A. S. Pozdnyaev, Oil economy, 3, 24-27 (2016)

5. E. N. Gorbunova, Taxes and Finance, 3 (39), 13-18 (2018).

6. Yu. N. Bobylev, Questions of economy, 6, 45-62 (2015)

7. M. V. Kashirina, M. A. Zhuravlev, Financial journal, 4, 53-59 (2016)

8. A. A. Gert, O. G. Nemova, K. N. Kuzmina, Economics and management, 64, 54-60 (2019)

9. N. V. Ponomareva, A. L. Lukovkin, Entrepreneur's Guide, 13, 45-54 (2020)

10. Tax Code of the Russian Federation. Part 2, Chapter 25.4 URL: http://www.consultant.ru.

11. Budget forecast of the Russian Federation for the period up to 2036. URL: http:// www.minfin.ru> main> Budzhetnyy_prognoz_2036 